Bol. Soc. Bot. México 46:89 (1984).

\title{
Nota sobre la ortografía correcta de Casimiroa calderonii Chiang et Medrano
}

El nombre de esta especie fue dedicado a una botánica (Bol. Soc. Bot. México 41: 23, 1981). El epíteto específico de este binomio debe concordar con el género de la persona a quien se dedica el nombre. De acuerdo con el Art. 73.10 del ICBN (Voss et al., 1983. International Code of Botanical Nomenclature. Regnum Veg. 111) el uso incorrecto de las terminaciones se trata como un error ortográfico que debe corregirse. Por lo tanto, el nombre correcto de la especie en cuestión debe ser Casimiroa calderoniae (fem.), en vez de C. calderonii (masc.).

Fernando Chiang. Departamento de Botánica, Instituto de Biología, Universidad Nacional Autónoma de México, Apartado Postal 70-233, 04510 México, D.F.

Chiang F. 1984. Nota sobre la ortografía correcta de Casimiroa calderonii Chiang et Medrano. Boletín de la Sociedad Botánica de México 46: 89. 